\title{
脂肪化生をきたした耳下腺筋上皮腫例
}

\author{
加藤 明子・藤村 武之・清水 隆・塩盛 輝夫 \\ 森尾崇・宇高毅・鈴木 秀明
}

\section{A Case of Myoepithelioma with Lipomatous Metaplasia of the Parotid Gland}

\author{
Akiko Katoh, Takeyuki Fujimura, Takashi Shimizu, Teruo Shiomori, \\ Takashi Morio, Tsuyoshi Udaka and Hideaki Suzuki \\ (University of Occupational and Environmental Health, School of Medicine)
}

\begin{abstract}
Myoepithelioma is a relatively rare form of salivary gland tumor, accounting for less than $1 \%$ of all salivary gland neoplasms. We herein report an extremely rare case of this tumor with lipomatous metaplasia of the parotid gland. A 50-year-old woman presented with a right-sided subauricular painless mass. Computed tomography, ultrasonography and magnetic resonance imaging demonstrated a $30 \times 20 \mathrm{~mm}$ well-defined ovoid tumor in the superficial lobe of the right parotid gland. A benign parotid tumor was clinically suspected, and she underwent superficial parotidectomy with preservation of the facial nerve. Histopathologically, the tumor consisted of spindle-shaped tumor cells arranged in solid and myxoid patterns containing abundant adipose tissue. Immunohistochemically, the tumor cells were positive for S-100 protein and $\alpha$-smooth muscle actin. Based on these findings, the tumor was diagnosed as myoepithelioma with lipomatous metaplasia. The postoperative clinical course was uneventful, and the patient is currently free from disease 36 months after surgery. The pathology of myoepithelioma and a possible pathogenesis in the occurrence of adipocytes in this tumor are reviewed from the literature.
\end{abstract}

Key words : myoepithelioma, lipomatous metaplasia, parotid gland

はじめに

筋上皮細胞は上皮と平滑筋の両者の性質を兼ね備えた 外肧葉由来の収縮性をもつ細胞である。この細胞は外分 泌能を有する唾液腺, 乳腺, 汗腺, 前立腺, 涙腺などの 組織に存在し，分泌物の分泌・輸送に関与していると考 えられている ${ }^{1)}$. 筋上皮腫は, 全唾液腺腫瘍中 $1 \%$ 未満の 比較的まれな疾患であるとされている21.最近 15 年間に おける本邦報告例でも耳下腺由来のものは 6 症例 $32 \sim 7)$ を見いだすに過ぎない.今回われわれは耳下腺に発生し， 脂肪化生をきたした，きわめて珍しい筋上皮腫の 1 例を 経験したので, 若干の文献的考察を加えて報告する.

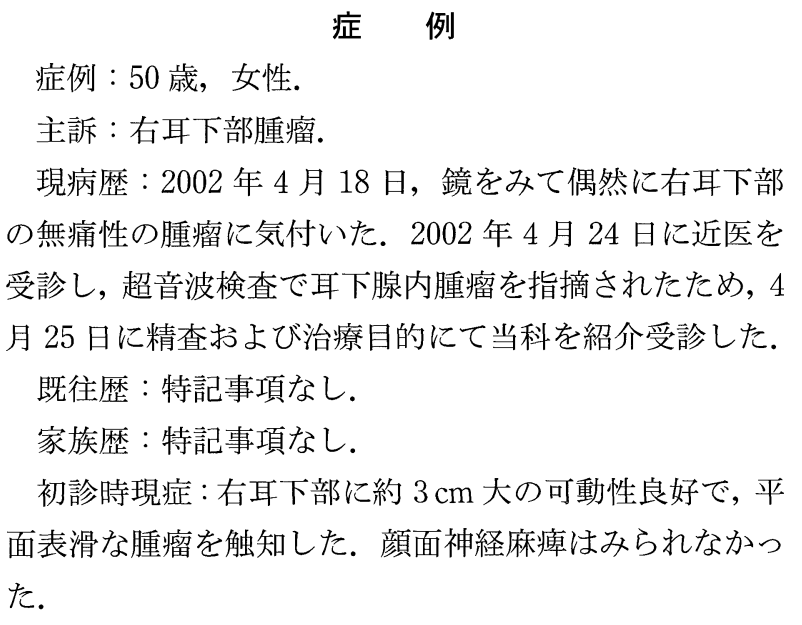




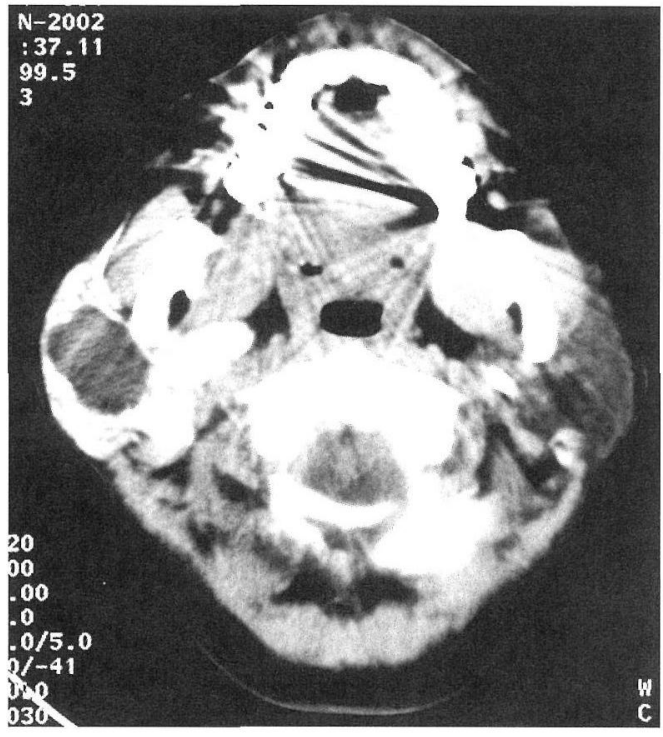

図 1 シアロ CT 所見 在耳下腺浅葉に，やや凹凹のある境界明瞭な腫瘍が認め られる。

画像所見：超音波検查にて，右耳下腺内に $3.3 \times 2.8 \times$ $2.0 \mathrm{~cm}$, 卵円型, 辺縁整, 内部エコー不均一で，内部に 線状に血流を伴う腫瘍性病変を認めた。単純および造影
CT ではともに耳下腺腫瘍と周囲の耳下腺実質との差が 明瞭でなかったため，シアロ CTを施行した。これによ り腫瘍は右耳下腺浅葉に存在し，やや凹凸を示すものの 境界明瞭であることが判明した（図 1)。腫瘍内部は筋組 織よりも X 線低吸收であった。造影 MRI 検查では，腫 陽は T1 強調画像で内部に多数の小さな高信号を含む低 信号領域, T2 強調画像では著明な高信号を示す領域とし て描出された (図 2)。テクネシウムシンチグラムにおい ては，右耳下腺内部の腫瘍と一致する部位に集積欠損領 域を認めた。またガリウムシンチグラムでは，異常集積 像は認められなかった。

臨床経過：触診所見およびシアロ CT 検査の所見より 総合的に判断した結果，耳下腺に発生した多形腺腫を最 も疑い，2002 年 7 月 1 日，全身麻酔下に右耳下腺腫瘍摘 出術を施行した。手術では顔面神経本幹より末梢側に神 経の剖出を進めていくと，腫瘍の内側部が顔面神経上下 枝の分枝間に陥入していた。周囲組織との癒着はみられ なかった。腫瘍は黄褐色均一，弾性軟で，肉眼的には脂 肪腫と類似していた。術中迅速病理検查では紡錘型細胞 を主体とする良性腫瘍との結果であったため，顔面神経 を温存した上で, 耳下腺浅葉切除の形で腫瘳を摘出した。 経過良好につき，2002 年 7 月 10 日退院した。以後外来

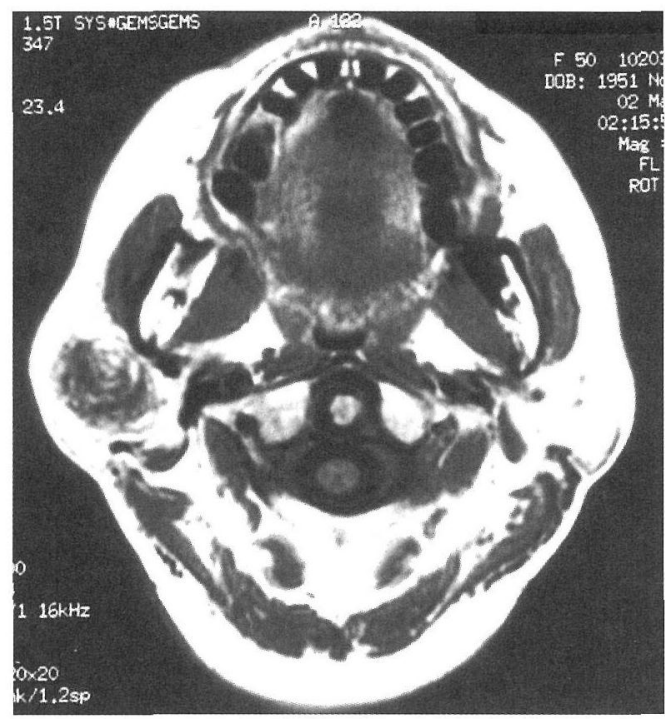

A

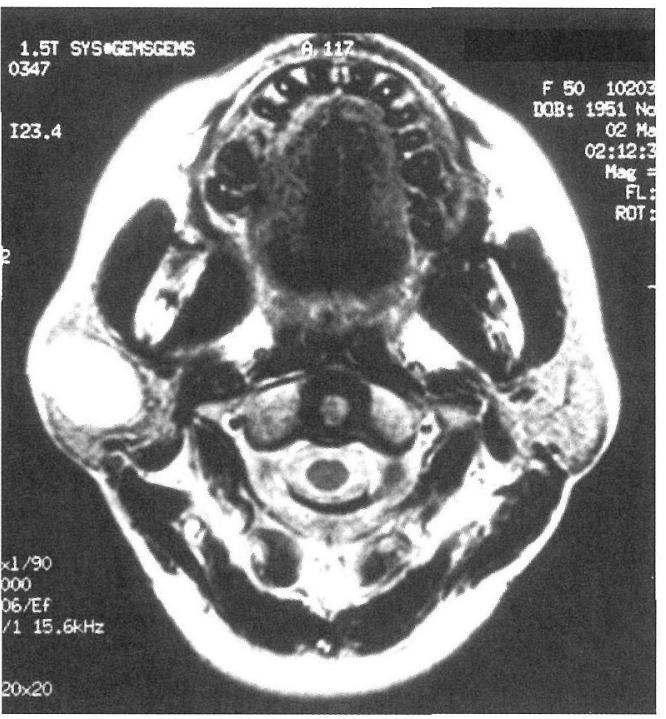

B

図 2 MRI 所見

$\mathrm{A} ： \mathrm{~T} 1$ 強調画像。腫瘍は内部に多数の小さな高信号を含む低信号を示す.

B：T2 強調画像。著明な高信号を示す。 


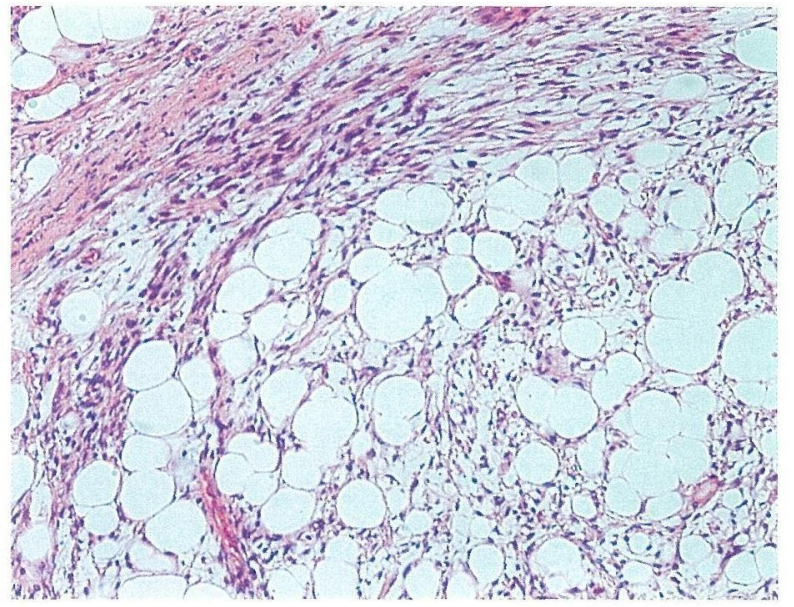

A

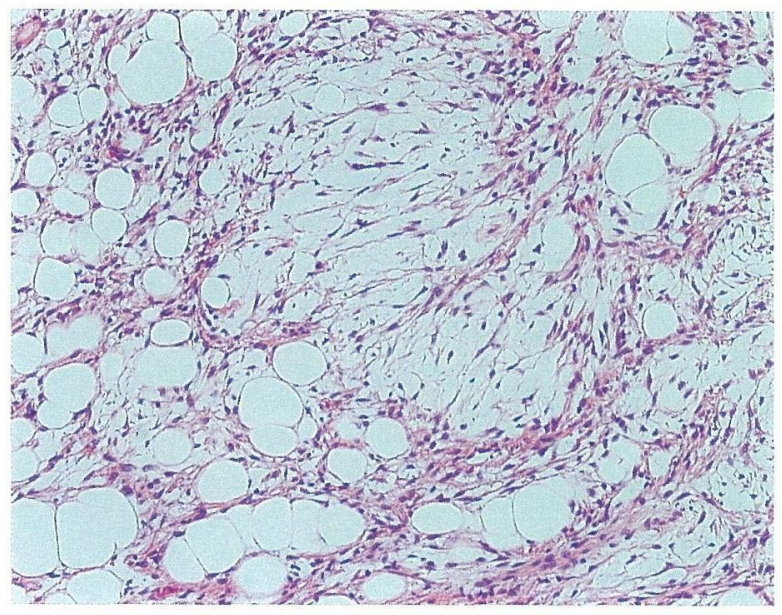

B

図 3 病理組織学的所見 $(\mathrm{HE}$ 染色, $\times 200)$

A：脂肪化生を伴う充実性の紡鍾形腫場細胞像.

B : 脂肪化生を伴う粘液様の紡鍾形腫瘍細胞像.

通院にて経過観察中であるが，3年を経た現在腫瘍の再 発はない。

病理組織学的所見：腫瘍内部には成熟した脂肪組織が 大量に含まれており，紡錘形腫瘍細胞吕充実性または粘 液様に増殖し，ごく一部腺管様の構造も散在していた。 また細胞の異型性，核分裂像および浸潤性発育はみられ なかった（図 3).免疫組織学的には，紡鍾型の腫瘍細胞 は S-100 蛋白， $\alpha$-smooth muscle actin（SMA）に陽性を 示し, サイトケラチン (AE1/AE3) に陰性であった。以 上の病理組織おうよび免疫組織学的所見より筋上皮腫と診 断された。

\section{考察}

筋上皮腫の組織発生を理解するには唾液腺の発生学的 知識を必要とする. 胎生期に外胚葉由来の幹細胞が付近 の中肧葉に移動し, その周囲の細胞と細胞塊を形成する。 その際，近位細胞塊は将来葉内導管細胞となり，遠位細 胞塊は介在部導管細胞, 腺房細胞, 筋上皮細胞に分化す る、唾液腺腫瘍の組織発生にはこうした胚細胞のどの段 階からなる腫瘍かを考えることが不可欠である。多形腺 腫の場合，腫瘍細胞は筋上皮之導管上皮への二方向性分 化を示すが，唾液腺腫瘍のなかには筋上皮への一方向性 分化のみを示すものも存在する。

1943 年, Sheldon ${ }^{8)}$ はいわゆる mixed tumor について検
討し, 筋上皮細胞由来の細胞の増殖がきわめて優位なも のを筋上皮腫と分類した。唾液腺筋上皮腫は，かつては 多形腺腫の一亜型とみなされていたが8), 1991 年の WHO 新分類加ら独立した疾患単位として記載され99, その発 生頻度は全唾液腺腫瘍の $1 \%$ 未満の比較的まれな疾患と されている. 好発部位は耳下腺が $50 \%$, 硬・軟口蓋が 26 \%，顎下腺が $12 \%$ あるが，すべての唾液腺に生じう る2). 唾液腺以外の臓器においては乳腺, 汗腺, 前立腺, 涙腺にみられることがある ${ }^{1)}$. 臨床的には緩慢な増殖を 示す無症候性の腫瘤として認められ, 肉眼的には通常線 維性の薄い被膜を有し，表面は平滑，割面は白色または 褐色少ら死白色均一の充実性の腫瘍である ${ }^{2)}$. 病理組織 型は，腫瘍を構成している細胞の形態により，紡鏵形細 胞型 (spindle), 形質細胞様細胞型 (plasmacytoid), 類上 皮細胞型 (epithelioid), 明調細胞型 (clear cells) および その混合型に分類される10). また充実性（solid）, 粘液様 (myxoid)，細網状（reticular）などの組織構築のパター ンがある9). WHO 分類では筋上皮腫は腺管への分化を示 さないとされている9) のに対し Dardick ら 1112) は全体の $5 \sim 10 \%$ 程度の腺管形成が認められても筋上皮腫として 許容している。 なお Barnes ら 2 は筋上皮腫における腺管 細胞の由来について, 発生学的に, 腫瘍発育の過程で正 常唾液腺構造が分離したもの，未熟幹細胞がまれに腺管 様成分を形成したもの, 高密度の筋上皮腫様上皮細胞を 
伴った不均一な多形腺腫のいずれかであろうと推測して いる. 本症例では病理組織学的所見より, 紡鍾形腫瘍細 胞が充実性または粘液様に增殖し, 腺管様構造はごく一 部だったことから，充実性，粘液様の組織構築をきたし た紡錘形細胞型筋上皮腫に分類された。また一部に腺管 を認めるため，WHO の箃密な基準とは矛盾する所見で あったが, その存在はきわめて散在性かつ孤立性であり, Dardick ら ${ }^{1112)}$ やBarnes ら ${ }^{2)}$ の報告も踏まえ, 筋上皮腫と 診断した。

今回の病理組織学的所見として特筆すべき点は, 筋上 皮細胞と成熟した脂肪組織とが混在していたことであ る. Skalova ら ${ }^{13)}$ は耳下腺における紡錘形の筋上皮腫瘍 と脂肪組織が混在した 4 例について免疫組織学的ならび に超微形態学的な報告をしている，それによると，筋上 皮腫における豊富な脂肪組織の存在は, 腺腫によって周 囲の脂肪組織が単に取り込まれたものではなく，腫腸性 筋上皮細胞の脂肪化生の結果であると考察している. 本 症例む Skalova ら ${ }^{13)}$ の報告例酒似しており, 脂肪化生 をきたしたきわめて珍しい紡鍾形細胞型筋上皮腫の 1 例 であった。

過去の報告例によると耳下腺筋上皮腫は MRI 上，T1 強調画像で低信号もしくは筋と同程度の信号, T2 強調画 像で高信号を呈するとされている5)。本症例での腫瘍は $\mathrm{T} 1$ 強調画像で内部に多数の小さな高信号を含む低信号 領域として描出されている。 その病理組織学的所見が脂 肪化生を伴う筋上皮腫であることを考慮すれば, $\mathrm{T} 1$ 強調 画像に抢ける多数の小さな高信号域は脂肪化生の部位を 反映しているものと考えられる。

免疫組織学的に S-100 蛋白は, 正常筋上皮細胞にはほ とんど反応性を示さず，腫瘍性筋上皮細胞にのみ反応を 示すことが多いといわれる.また， $\alpha$-SMA は正常筋上皮 細胞に反応を示さないが，腫瘍性筋上皮細胞にもさまざ まな程度に反応を示す，サイトケラチンも $\alpha$-SMA にお ける反応とほぼ同様であるが，形質細胞様細胞型の腫瘍 細胞にはさまざまな程度に反応を示す一方で，紡錘形細 胞型の腫瘍細胞には反応が弱いことが多い ${ }^{3)}$ 。このよう に本腫瘍が免疫組織学的染色に多様性を示す要因とし て，二階ら ${ }^{14)}$ は，腫瘍性筋上皮細胞が異常な細胞分化や 化生によって修飾され，正常ではみることのない形質発 現を伴うためではないかと推察している. また一方で, Ellis ら 10) は, 筋上皮腫の腫瘍細胞には必ずしも免疫組織 活性が全症例に認められるわけではないことを報告して
いる. 自験例では, 免疫組織学的染色の結果 S-100 蛋白 および $\alpha$-SMA が陽性であり, HE 染色での組織像と総合 して，筋上皮腫との確定診断にいたった。

1991 年以降の 14 年間に報告された本邦の良性耳下腺 筋上皮腫は，われわれの涉猟しえた限りでは 6 例3) 7) あり, 年齢は $29 \sim 70$ 歳にわたり, 平均 50.7 歳であった。 治療は全例で手術が行われており，5例が浅葉切除，深 葉由来の 1 例で耳下腺全摘術が行われていた。組織型は 紡鍾形細胞型が 3 例，紡鍾形細胞型と形質細胞様細胞型 による混合型が 2 例, 形質細胞様細胞型が 1 例であった。 本腫瘍の性質は良性の多形腺腫と類似し, 治療も多形腺 腫と同様に行われる，筋上皮腫の治療としては，安全域 をつけた外科的切除が必要であり，耳下腺浅葉筋上皮腫 に対しては, 浅葉切除が推奨される.十分な安全域をとっ た完全切除が図られた症例においての再発はごくまれで ある ${ }^{11}$. しかしながら，多形腺腫と同様に局所浸潤や局 所再発をきたす例があり，ときに悪性変化を起こし急速 な增殖をきたすこともあり ${ }^{12)}$, 術後の注意深い経過観察 が必要である.

\section{まとめ}

右耳下腺に発生し, 脂肪化生をきたしたきわめて珍し い筋上皮腫の 1 例を経験した。耳下腺浅葉切除術を施行 し，術後再発もなく経過は良好である。

病理組織学的に腫瘍内部には成熟した脂肪組織が大量 に含まれており充実性，粘液様の組織構築をきたした紡 鍾形細胞型筋上皮腫に分類された．筋上皮腫内に脂肪組 織が発生する機序について文献的に考察した。

\section{参考文献}

1) Scuibba JJ and Brannon RB : Myoepithelioma of salivary glands: report of 23 cases. Cancer $49: 562 \sim 572,1982$.

2) Barnes L, Appel BN, Perez H, et al. : Myoepitheliomas of the head and neck: case report and review. J Surg Oncol 28:21 28, 1985.

3）名倉 功, 重松久夫, 志田裕子, 他：耳下腺に発生した筋 上皮腫の 1 例. 口科誌 $49: 662 \sim 665,2003$.

4）吉村勝弘, 兵佐和子, 田中 斉, 他: 耳下腺筋上皮腫例. 済生会吹田病院医学雑誌 9: 95 98, 2003.

5）佐藤美和子，吉原俊雄：耳下腺筋上皮腫の 2 例と文献的考 察. 耳鼻 $47: 5 \sim 10,2001$.

6）政田佳子, 細川 瓦, 橋本裕之, 他：耳下腺の筋上皮腫の 1例. 住友医誌 $18: 119 \sim 122,1991$.

7）日比一光，広川満良，真鍋俊明，他：耳下腺に発生した筋 
上皮腫の 1 例. 岡山外科病理雑誌 $35: 54 \sim 55,1998$.

8) Sheldon WH : So-called mixed tumors of the salivary glands. Arch Pathol $35: 1 \sim 20,1943$.

9) Seifert G : Myoepithelioma. World Health Organization international histological classification of tumours. Histological Typing of Salivary Tumours $2^{\text {nd }}$ Edition (ed by Seifert G). p 12, Springer-Verlag, Berlin, 1991.

10) Ellis GL and Auclair PL : Tumors of the salivaly glands. Atlas of tumor pathology. $3^{\text {rd }}$ series, Fascicle 17.: Armed Forces Institute of Pathology (ed by Ellis GL and Auclair PL). pp 57 68, Washington, D.C., 1996.

11) Dardick I : Myoepithelioma: definition and diagnostic criteria. Ultrastruct Pathol $19: 335 \sim 345,1995$.

12) Dardick I, Thomas MJ and van Nostrand AW : Myoepiteliomanew concepts of histology and classification: a light and electron microscopic study. Ultrastruct Pathol $13: 187 \sim 224$,
1989.

13) Skalova A, Starek I, Simpson RH, et al. : Spindle cell myoepithelial tumours of the parotid gland with extensive lipomatous metaplasia: a report of four cases with immunohisochemical and ultrastructural findings. Virchows Arch $439: 762 \sim 767$, 2001.

14）二階宏昌, 小川郁子, 高田 隆, 他：唾液腺腫瘍の免疫組 織化学 腫瘍性筋上皮の染色所見を中心に. 病理と臨床 7: $574 \sim 581,1989$.

原稿受付：平成17年 1 月 11 日

原稿採択：平成17年 2 月 16 日

別刷請求先 : 藤村武之

厂807-8555 北九州市八幡西区医生ヶ丘1-1 産業医科大学医学部耳鼻咽喉科学教室 